\title{
Representations of Ethnicity in Journalism
}

\author{
Multiculturalist Transitions \\ on the Pages of a Finnish Daily
}

\author{
SARI PieTIKÄInen
}

\begin{abstract}
This article examines ethnic representations in the Finnish news discourse. Adopting a critical discourse analytical framework, the article examines textual manifestations of ethnic representations, the journalistic practices impinging on them and, finally, the significance of ethnic representations in the news. The study suggests that the marginalized position of ethnic minorities, journalistic practices and the insensitivity of the representational power of the news discourse together result in ethnic representations that contribute to the fragmentation of community, rather than to a sense of belonging.
\end{abstract}

Key Words: press news, ethnicity, representation, critical discourse analysis, journalistic practices

\section{Introduction}

The increasing multiculturalism in Nordic countries poses a challenge to journalism. Given the signifying power of the news media, the ways in which news represents various ethnic communities, issues related to multiculturalization and the changing society have significance in relation to the positions of various groups and to the relations between them (Tufte, 2003). After all, news is one of the most influential public spaces of contemporary society, perceived as offering trustworthy and accurate stories about the world, its events and people (Allan, 1999; Berkowizt, 1997; Cottle, 2000). It can be argued that news contributes to the ways in which we see the world and what we see in it (Grossberg, Wartella \& Whitney, 1998).

Previous research shows that journalism seems to have an ambivalent role in ethnic relations. In everyday talk and public discussions, much of ethnic prejudice, the disadvantaged position of ethnic minorities and even racism are attributed to news publicity. The news coverage of ethnic minorities is often described as biased and partial, favouring majority groups over ethnic minorities, and ethnic representations conveyed by news are claimed to be stereotypical, often negative and sometimes racist (Allan, 1999;

Sari Pietikäinen, D.Phil., Researcher, Department of Communication, P.O. Box 35, FIN-40014 University of Jyväskylä, sari.pietikainen@jyu.fi 
Campbell, 1995; Cottle, 2000; Hall, 1995; ter Wal, 2002; van Dijk, 1991). Moreover, minority groups have continuously expressed their worry about negative reporting and have argued that news reports about them are, at best, one-sided or irrelevant and often negative and discriminatory (Aikio \& Aikio, 2001; Ross, 2000). At the same time, however, national and international journalist associations have stated their commitment to fair ethnic reporting in order to prevent and oppose racism. Journalists have also defended their independence and their duty to report on "things as they are" - negative points about ethnic minorities included - and have drawn attention to the practical limitations and conditions of their daily work: lack of time, money and other resources (Pietikäinen \& Luostarinen, 1997; Zelizer, 1997). Further, individual cases of ethnic reporting, as well as continuous attempts by various ethnic activity groups to gain access to the news, point towards the empowering potential of the news media.

This potential of journalism to contribute both to feelings of communal and national belonging and to strengthening the activity of citizens as well as journalism's power to exacerbate differentiation and separation (Pietikäinen, forthcoming) makes it vital to examine how news media cover ethnic issues. This research interest is underpinned by the constructivist approach, which emphasizes that news is the result of a complex combination of journalistic values, commercial imperatives, journalistic practices and individual choices (see, e.g., Allan, 1999; Hujanen \& Pietikäinen, 2004). This means that although there are conditions a news report must meet, there is always a degree of variation and freedom involved in composing news stories. A further relevant aspect is that the news is discursive. That is to say, the ways in which the news is made, presented and interpreted are profoundly tied to the use of language. This kind of understanding of news stems from a view on discourse as being a part of social practices - a view advocated in critical discourse analysis. From this perspective, news is seen as being shaped by situations, institutions and social structures, and conversely, also shaping them (Chouliaraki \& Fairclough, 1999; Fairclough, 1992; Fairclough \& Wodak, 1997; Jäger, 2001). This means that different social, historical and political events and phenomena are partly manifested discursively, which implies in turn that it is possible to study, for example, ethnic representations and relations through analysis of news discourse.

This article examines ethnic representations in mainstream press news. I explore the dynamics of ethnic representations of minority and majority groups through critical discourse analysis of news texts dealing with ethnic changes in Finland published in the leading Finnish daily, the Helsingin Sanomat. The article is based on a more comprehensive study on ethnic differentiation in the Finnish news discourse (Pietikäinen, 2000). The time period under scrutiny (1985-1993) captures a transition in this Nordic country, from being a place of emigration to a (more) multicultural society, thus presenting a challenge to journalism. As relatively rapid multiculturalization was a novelty to the Finnish media during the time studied, the period can be considered as a kind of transition in which journalism - as well as society as a whole - sought a way to deal with new ethnic groups. It is therefore interesting to examine how the leading quality newspaper, the Helsingin Sanomat, reported on these changes.

I begin by locating the present study in relation to social context as well as to previous research in this area. Then, I introduce a critical discourse analytical approach to examining ethnic representations in the news as well as the data and methods of this research, followed by a presentation of the findings of the study. In conclusion, the significance of ethnic representations in news is discussed. 


\section{Background}

Finland is a Nordic country with the reputation of being one of the most ethnically homogeneous nations in Europe. Until recent years, emigrants have outnumbered people moving to Finland. Also, traditional ethnic groups are relatively few and small. Finland takes pride in the organization of human rights issues within the country, exemplified by the position of one linguistic minority, the Finnish-Swedish.

The period under investigation, 1985-1993, is particularly interesting with respect to ethnicity: it was a period of gradual development for Finland, from a relatively homogenous country to an increasingly multicultural society. In 1985, Finland agreed for the first time to receive an annual quota of one hundred refugees, which meant setting up new organizations, systems and legislation. These changes speeded up discussions about Finnishness, 'otherness' and 'usness'. The next major change came in the form of the collapse of the former Soviet Union. One practical consequence of this event was that, for the first time, the long eastern border between Finland and the Soviet Union became reachable by asylum seekers. Finland was the first safe country they entered and was, therefore, under obligation to process their applications.

Hundreds of refugees, particularly from Somalia and the former Yugoslavia, arrived via this passage and applied for asylum in Finland. Consequently, Finland's principles, legislation, and attitudes towards immigration and refugees were all put to the test. Although the number of applicants was marginal in comparison to those of other European countries, the rapid growth in numbers led the government to believe that there would be many others to come. Also, a deep economic recession and a high number of unemployed people characterized the last few years of the studied period. This worry manifested itself in the new strict legislation concerning asylum seekers that came into force in 1993. Since the early 1990's, the preparation for membership in the EU, which became a reality in 1995, impassioned the discussion about Finnishness. In sum, these relatively rapid and striking changes posed a challenge to Finnish journalism, which has a pivotal role in representing and interpreting them. Examining the characteristics of HS's coverage of ethnic issues, therefore, gives us an opportunity to see reactions and development in the line of reporting in one of the leading Finnish news media.

\section{Ethnic Minorities in the Press}

News coverage of marginalized ethnic groups across the decades, continents and media seems to be surprisingly - and depressingly - homogenous and unchanging. The conclusion already drawn by the Kerner commission in 1968 - news media had kept itself for too long in the white world, looking at the world from a white perspective (Kennedy, 1998, 76-77; Newkirk, 1998, 58-59) - has been supported in different ways in a considerable body of research conducted both in Europe and the US (e.g., Allan, 1999; Barker, 1999; Campbell, 1995; Critcher, Parker \& Sondhi, 1997; Hartman \& Husband, 1974; ter Wal, 2002; van Dijk, 1991). The collective findings of these researches paint a rather depressing picture of under-representation, negative problem-orientation, voicelessness and stereotypical juxtapositioning of ethnic minorities in the news.

One prevailing feature of the news coverage of ethnic minorities is the lack of it. Typically, only one or two news reports are published per copy - a finding established previously in the news coverage of the British press in the late 70s (Troyna, 1981) and found again ten years later in British and Dutch press news coverage (van Dijk, 1991) and, during the 1990s, in German (Butterwegge, 1996) and Swedish (Löwander, 1997) press news coverage. In terms of quantity, journalism does not seem to give much space 
to ethnic minorities. Only extraordinary ethnic events - such as dramatic changes, crimes, or totally new situations - constitute exceptions to this scarcity of ethnic news. The newsworthiness of ethnic minorities is - similar to that of many other marginalized and powerless groups - tied to extraordinariness and conflict.

Another reiterated finding is the representation of ethnic minorities within the context of problems, crime and disturbance (see, e.g., Campbell, 1995; Löwander, 1997; Reisigl \& Wodak, 2001; ter Wal, 2002; van Dijk, 1991). A study by Hartman and Husband (1974) on the news coverage of race in the British press in the 1960s established that the topics most frequently covered were immigration, race relations and crime. In a study of the British and Dutch press, van Dijk (1991) found that, in 1985, the British press most frequently reported topics that involved "urban disturbances", "race" relations and politics, while the Dutch press focussed on immigration, discrimination, and crime. In their study of US news magazine coverage of Black-Latino interaction in 1980-1992, Shah and Thornton (1994) discovered that the most common topics included conflicts, racism and violence. Similar frequencies have been found in other European countries (Löwander, 1997; Butterwegge, 1996; Reisigl \& Wodak, 2001; Wodak 1996)

News coverage of ethnic minorities is also characterized by their voicelessness. For instance, van Dijk (1991) discovered that minority organizations, leaders, and spokespersons had less frequent access to the media than did their white mainstream counterparts, even when the topics concerned them directly and even if there were minority experts available to give their opinions. Similarly, in his study of Australian press coverage of Vietnamese gangs, Teo (2000) found that ethnic minority members were quoted less than one-quarter of the time as compared with white members. Löwander (1997) noticed an interesting difference in the use of news sources by Swedish television broadcasters when reporting on racism and anti-racism: when the news coverage dealt with racial violence, racism and Nazism, the broadcasters used the police as their main informant, whereas in the case of anti-racism, they tended to use politicians. Immigrants or anti-racist activists were rarely used as sources of information in either case.

Stereotypical representations of 'us' and 'them' appertain to news coverage of ethnic minorities. For instance, in the study of press coverage of Mike Tyson's trial, Lule (1995) discovered that the portrayals drew from stereotypes of the African American: the animal, sex-obsessed savage and helpless, hapless victims (see also Fiske, 2000). According to Brookes' (1995) study, Africans were portrayed in the British press news with stereotypes of the primitive, savage, murderous and violent, and the whole African continent appeared as a homogeneous block embodying violence, helplessness, human rights abuse, and lack of democracy.

Detailed linguistic analyses have also shed light on how language works subtly with respect to, for instance, who is represented as an active or passive actor, who is the receiver of what kind of actions and whether some actors are omitted; in brief, who is doing what to whom. For instance, Brookes (1995) argues that, with regard to agency, the general trend in the British press was for African participants to be consistently constructed as direct agents of processes such as violence, repression, verbal wrangling, and requests for help. When describing processes of peace and negotiation, the agency was, in turn, allocated to Western participants, and the African participants were generally positioned in the background through attenuation or omission. (Brookes 1995, pp. 474-478, pp. 482-483.) Also, a linguistic analysis of news texts covering the Sami, the indigenous people of Scandinavia, showed that the majority members were most frequently allocated the roles of doers and decision makers, whereas the Sami were mainly presented as objects of majority actions, regardless of their own political activity (Pietikäinen 2003). 
Even the new journalistic innovations and attempts to report ethnic minorities differently and more positively seem doomed to reproduce old, negative stereotypes and generalizations (Parisi, 1998, pp. 238-239). For instance, Cottle (2000, pp. 11) argues that, despite the best intentions, 'multiculturalist' representations of ethnicity may actually serve to reinforce culturally sedimented views of ethnic minorities as the "Other" and simultaneously appear to portray structural disadvantage and continuing inequality as marginal. For example, an unintentional outcome of portraying African Americans in more positive ways can create an impression of black people's social advancement, thus undermining black people's claims on white resources and sympathies (Campbell, 1995; Lule, 1995). In sum, the press news tends to represent ethnic groups negatively and ignore the structural inequalities and racism experienced by ethnic minorities.

\section{A Critical Approach to Discourse Analysis}

Critical discourse analysis (CDA) is a broad term for the theoretical and analytical frameworks used in those branches of sociology and linguistics that are interested in the power of discourse (for overviews see, e.g., Fairclough \& Wodak, 1997; Toolan, 1997; Wodak, 2001). The focus is on socially conditioned and consequential use of language: on the structures, routines and norms that frame, limit and enable the ways in which language is used, but also on the ways in which the use of language contributes to the construction of knowledge, identities and relations between groups of people. This dialectical view of the relationship between language and society is, as Fairclough (1992, pp. 64) puts it, an import from Foucault's discussion of the discursive formation of objects, subjects and concepts. In the CDA literature, this view is captured in the conceptualization of discourse as social practice (Chouriaraki \& Fairclough, 1999, pp. 28-29; Fairclough, 2001, pp.122-123; Fairclough \& Wodak, 1997, pp. 258-259; van Leeuwen, 1993, pp. 193; Wodak, 1996, pp. 15).

This kind of conceptualization of discourse gives it a powerful position. Discourse is seen not only as representing the world, but also as constructing it. Because it is action, it also has certain consequences and conditions. Due to its social embeddedness, various social, historical, and political phenomena, structures, and events are partly manifested in discourse. It is therefore possible to study, for instance, racism, sexism, political and social conditions, and historical events through analysis of discourse. This also explains why discourse is considered to be a salient feature of contemporary societies and, as such, an interesting area of research.

This conceptualization of discourse leads us to the second central tenet of CDA, namely that of criticality. Sharing the goals and aims of critical theory, CDA concentrates on the discursive side of power (Fairclough, 1992; van Dijk, 2001; Wodak, 2001). Discourse may have ideological effects: it can help to reproduce, maintain and resist unequal power relations between, for instance, social classes, genders, ethnic groups through the way in which it represents events and positions people (Fairclough \& Wodak, 1997, pp. 258). In the domain of ethnicity in journalism, this means that there is nothing inherently fixed about news representations of ethnic minorities and the majority or the relationship between them. Rather, ethnic representations are socially formed and fixed in and through discourse. Consequently, the aim of the analysis is to show systematic links between texts, discourse practices and social practices (Fairclough, 1995, pp.116-117). This entails mapping different aspects of discourse that are simultaneously at work in a particular piece of text, namely: 1) the actual usage of language, 2) the practices of production and consumption of the text, and 3 ) the wider 
socio-political context and significance of the text. The analysis involves utilization of different types of methods, including linguistic, textual, intertextual and content analyses (Wodak, 2001).

In many respects this study constitutes a critical discourse analysis. My point of departure here is discourse as social practice. Accordingly, by discourse I mean use of language that is constructed by and constructs the social. Here, this refers particularly to the assumption that news discourse about ethnic minorities contributes to the representations of ethnic identities and the relations between suggested identities. At the same time, social, institutional, professional and contextual norms, routines and values contribute to the ways in which news discourse is made and used. I focus particularly on journalistic practices impinging on ethnic representations in news. The critical dimension implies that my aim is to contribute to our awareness of the power of news discourse and the significance of ethnic representations.

\section{Analysing Ethnic Representations in News Discourse}

The data for this study consist of 1,189 domestic news reports and editorials about ethnic affairs published in the leading Finnish national daily, Helsingin Sanomat, during the period 1985-1993. The Helsingin Sanomat (HS) was selected because it is the largest Finnish daily, regarded as the leading quality newspaper and widely respected. In terms of its resources as regards finances, number of journalists and standards of reporting, HS is often considered superior. On the whole, HS has almost an institutional position in Finnish society, and it acts as an official voice in the public sphere. As a newspaper located in the capital, HS was in the frontline of reporting about multiculturalization in the Finnish society: the vast majority of the newcomers as well as organizations and political decision-making are centred around the capital, i.e. Helsinki, area. Helsingin Sanomat was the obvious choice also because the regional newspapers started to cover ethnic minorities more extensively only during the (late) 1990s, after their readership and regions had been modified towards (more) multiculturalism. In brief, given the position and resources of the Helsingin Sanomat, its news reports on ethnic minorities are significant and powerful, and news reporting may be expected to be conducted according to the best journalistic standards.

News discourse about ethnic minorities, then, is analysable in terms of textual features that contribute to ethnic representations and that are indicative of journalistic practices impinging on the news discourse. Taking the CDA stance on the analysis of news discourse, and by drawing on earlier research on news coverage of ethnic minorities and on discursive representations of ethnicity, I analyse a set of textual features potentially central in representing ethnicity in the news. These features are: 1) topics of news texts, 2) topic hierarchization in news texts, 3 ) text participants and quotation patterns and 4) intertextuality of the news texts with regard to the discourses drawn upon. News topics form the domain of ethnic representation and give some indication as to what the HS journalists found newsworthy as regards ethnic minorities. The topic order, i.e. which topics were put in the headlines and at the beginning of the news texts, highlights the generic structure of the news reports as well as the journalistic prioritization of different topics. Text participants and quotation patterns indicate what parties were given access to the news by the journalists and what parties the journalists saw as relevant and trustworthy news sources in a given topic. Intertextual analysis in terms of discourses shed light on the ways in which the texts echo previous texts, borrow significations across different situations, institutions and contexts and rearticulate them. Following the 
CDA framework (Fairclough 1992, 2003; Fairclough \& Wodak, 1997), a discourse, as a countable noun, is here understood to mean language used in representing a given social practice from a particular point of view. There can, therefore, be different discourses available to and used by one social phenomenon.

Using different types of methods to analyse discourse is yet another characteristic of CDA. In systematically examining the textual features of HS news discourse on ethnicity, I have employed several methods. The patterns of ethnic representations in terms the topics, topic hierarchization, text participants and quotations were examined with the help of content analysis. As the data comprised over 1,000 news items, they were analysed using quantitative means; the news items were coded into an SPSS database using 37 variables including, e.g., main topics, topic order in texts, majority and minority participants, direct and indirect quotations (for details see, e.g., Pietikäinen, 2000). Statistical analysis of the frequency and patterns of these variables provides an overview of the characteristic ways of representing ethnic groups. Discourses drawn on in texts are analysable in terms of a set of textual features expressing a particular discoursal meaning related to ethnicity. The starting point of this analysis was to identify these discourses, supported by an amalgam of textual features that cue the discourses. The explication of discourses involves an interplay of several categories of textual features including topic, participants, vocabulary, and grammatical choices. Further, intertextual analysis presupposes social, cultural and contextual knowledge about other texts available, social context and practices of text production, as it aims to locate a particular text in relation to other texts and discourse practices impinging on the production of the text (Fairclough, 1995, pp. 61). For the present study, this meant acknowledging the sociopolitical context in which the texts were made as well as the journalistic practices framing them. Next, I present and discuss results that are particularly relevant to ethnic representations in news discourse. By bringing together findings from different analyses, my aim is, following the CDA perspective, to shed light on the various complementary textual aspects of news discourse, each of which contribute to ethnic representations.

\section{Patterns of Ethnic Representation in the HS News Discourse}

To participate in the public discussion mediated by journalism, one must first gain access to this public arena. In the Helsingin Sanomat, such access was rarely given to ethnic minorities: during the time period studied, the paper published, on average, only 132 ethnic articles per year and less than 0.4 items per copy. This number is very low when compared with the tens of domestic news reports and the two to three editorials published in the paper daily (Pietilä \& Sonderman, 1994), or when compared with reporting frequencies found elsewhere (Löwander, 1997; van Dijk, 1991).

The analysis of topics of news texts offers a way to map the domains in which the ethnic minorities were represented and is also indicative of the journalistic practices applied, particularly with respect to news criteria. Altogether, HS reported on 47 different topics during the nine years examined. Most topics were mentioned only in passing: 16 topics out of 47 were reported less than 20 times. These less emphasized topics were closely related to ethnic minorities' everyday life in Finland, aspects such as housing, education, employment and their own culture. Instead, the emphasized aspects of the multiculturalization of Finnish society were closely related to the officials and authorities: the most frequently covered topics dealt with permits, numbers, legislation and politics.

A look at the topic frequency per year under study illustrates reactions to the ethnic change and the gradual development of the journalistic line of reporting. During the first 
four years under scrutiny, HS focussed on Finnish alien and refugee policy and law. This topic was discussed particularly in relation to the critique from other Nordic countries towards Finland's very strict refugee policy and the reactions and opinions of various Finnish politicians. Although the novelty of the situation may offer an explanation for the extensive coverage of these topics at the time, wittingly or not, through this sort of coverage HS contributed to people's concerns about an ethnically changing Finland. A period of more heterogeneous news topics was seen in 1989-1991. HS wrote about the 'flood of foreigners' and numbers of foreigners, but also about discrimination and racism as well as about the political rise of the Sami. The emphasis of the coverage shifted from (international) politics to the sphere of domestic affairs: the actual consequences of multiculturalization of the Finnish society. However, during the last years under study, a rather homogeneous consensus was reached on what was particularly newsworthy about ethnic minorities: residence permits and crime. Thus, in a rather short period of time, HS ended up representing ethnic minorities and newcomers as a potential source of problems - a line of reporting that still seems to continue in HS and is being adopted in other news media in Finland around the turn of the millennium (Raittila, 2002).

The frequency and the generic structure of news texts indicate the importance of various topics: topics expressed in the headlines and at the beginning of news texts are considered most relevant, striking and captivating aspects of the event (Bell, 1998). In the case of the HS news coverage, these aspects were the nature of change, tools for controlling it and one easy-selling consequence of it; thus, the most frequently occurring topics in the headlines were immigration to Finland, the residence permit decision, the Finnish alien law and crime.

If we turn to look at the patterns of how minority and majority groups were represented in the coverage, the two participant groups were described differently; the imbalance found in previous studies (Butterwegge, 1996; van Dijk, 1991) between ethnic minorities and the majority in terms of number of mentions, details given or quotation patterns applies to HS too. On average, members of the majority were mentioned 1.5 times more often than were minority members. Particularly, various officials, authorities and politics were granted space. Further, in over $70 \%$ of the texts, further details of the majority participants were provided, such as their name, occupation or status. In comparison, the corresponding figure for minorities was a little over $40 \%$. In this way, Finns were given an identity whereas the minority members remained faceless, abstract refugees or foreigners. Furthermore, while the majority members were quoted on average 1.3 times per text, minority members were quoted in every third text only. This means that the majority was predominantly used as a news source and given access to the news.

\section{Discursive Identifications at the Borders}

Out of the various aspects of multiculturalizaton of the Finnish society, HS reported most frequently on issues and events focussing on the borders - literally or figuratively - of Finland and Finnishness. The three most frequently reported topics were residence permit decisions, number of newcomers and immigration to Finland. The frequent reporting of these topics established them as the most newsworthy and as legitimate domains to write about in conjunction with ethnic change in Finland.

The most frequent topic, Residence permit decisions $(24 \%$ of 1,189$)$, typically dealt with questions of whether a particular group or individual will be allowed to enter or to stay in the country, and if so, what status should be granted. The following headlines illustrate this topic: 
Fewer residence permits granted to asylum seekers than before (HS 7.4.1992)

Yugoslavians arriving to Finland are granted a residence permit (HS 13.8.1992)

The reoccurrence of this topic establishes the question of legal grounds for entering and staying in the country as a primary area in which to discuss multiculturalization of Finland. Residence permits constitute a majority, official perspective on ethnic change, emphasized in the texts by the patterns of text population and quotations: the most frequently mentioned majority participant was the Finnish parliament, whereas the most frequently mentioned minority participant was the anonymous, abstract "refugees". This means that, rather than actually focussing on groups arriving in Finland, the news texts dealt with anonymous, often non-specified refugees. Further, the majority participants were quoted on this topic almost five times more often than were the minority participants. This indicates that the HS journalists overwhelmingly used majority participants as their primary news source. Given that the most frequent minority participant was the abstract refugee, this is no wonder: it is hard to interview 'a refugee' and refugees do not produce PR-materials or organize press conferences. On the whole, the discussion about residence permits was, above all, a discussion amongst the Finnish authorities about an ethnically changing Finland and Finnishness.

This is also realized in the intertextual features of news texts about the topic: the texts frequently draw on discourse that could be called Identification discourse. In terms of ethnic representation, this discourse generated attempts at providing criteria for a "real Finn" and for a "genuine" refugee and, conversely, for "non-Finns" and "false" newcomers. The simultaneous identification of 'us' and 'other' is typical for ethnic representations, as construction of identity inevitably means defining the other and the difference between the two (Hall, 1996). Often identification of the authenticity of newcomers in regard to their Finnishness or to being a refugee worked in synchronicity in the texts, as the examples below show.

The first example comes from a news report dealing with Ingrian remigrants. This ethnic group constitutes a heterogeneous and, to some extent, contested minority, who used to live nearby St Petersburg and have a strong connection to the Finnish culture and language. However, due to the suppressive ethnic politics of the Soviet Union, ethnicities were repressed during the communist rule resulting in, for instance, generations of Ingrians who did not command the Finnish language. In 1992, in accordance with the proposal of the Finnish president, Mauno Koivisto, a new law of Ingrian remigration was passed: As a consequence, Ingrians who can prove that they themselves, one of their parents or at least two of their grandparents can be classified in Russian Documents as Finns have a right to (re)migrate to Finland, regardless of whether any of them have actually ever lived in the territory of Finland. So far, over 20,000 Ingrian remigrants have arrived (Davydova, 2001, pp. 55). However, the multiple identities of these remigrants, as well as their lack of command of Finnish language, have been a source of ambiguity in Finland. The following example illustrates these reactions. The first excerpt is a direct quotation from a statement given by Markku Leijo from a special social security office in Helsinki. The subtitle is given by the newspaper.

From real Finns to the totally Russian

Personally, I think the problem is the notion of remigrant itself. Traditionally, it was used to refer to such people, who had stayed in Australia for, say, ten years and who wanted to return to Finland. They were clearly Finns, they had Finnish names, they spoke Finnish and knew Finnish culture. The background of Ingrian 
remigrants can be anything. From obvious Finns to complete Russians. Despite permits, some of them clearly have nothing to do with Finnishness. (HS 31.8.1992)

This excerpt exemplifies explicitly a great deal of the public discussion on the multiculturalization of Finland. It assumes an essentialistic view on Finnish identity relying on the idea of one clear, authentic Finnishness, which can be identified and displayed by a set of unchanging features, such as language and names (Woodward, 1997). The excerpt echoes the slogan 'one nation-one language' used during the national appraisal and independence struggle during the late 19th and early 20th century, ignoring now, as then, that Finland has always been culturally and linguistically heterogeneous although not due to vast immigration (Dufva, 2002).

Another aspect of Identification discourse was positioning the newcomers into a continuum of honest-dishonest. This is illustrated by the next example, which comes from a news report with the headline An increasing number of Eastern tourists try to pass as an Ingrian.

... some of them (Ingrian remigrants) are economic refugees moving with sincere intentions after hearing gossip that promises them a better future. Some, on the other hand, enter the country by misleading the authorities. In addition, some of the real remigrants have been discovered abusing the social security system. If the applications for remigration were handled in the country of departure, real and honest remigrants would probably not have any reason to come to stay in Finland on a tourist visa. The possibility of getting money from social security while staying on a tourist visa should be abolished. (HS 1.9.1992)

The discourse positions the newcomers in a restrictive passport control; it is not enough to be a 'genuine' Ingrian remigrant or asylum seeker, one also has to be impeccable. The Finns are represented as sensible and responsible people: welcoming and assuming a responsibility towards 'genuine' and 'honest' newcomers, and watchful and rejecting towards other kinds of migrants or refugees. These types of texts may be interpreted as belonging to a wider frame of reference, namely that of ethnic juxtaposition, a typical characteristic of the relations between different ethnic groups (see, e.g., van Dijk 1991; Hall, 1997). Characteristically, ethnic juxtapositioning sets up a symbolic difference between two ethnic groups by contrasting them and referring to differences in appearance, habits, languages, or personal characteristics such honesty, trustworthiness or working habits. Ethnic juxtapositioning, also at work in the texts examined, often involves positive self-representation and negative other-representation.

The second most frequently covered topic was number of foreigners $(19 \%$ of 1,189$)$. This topic involved issues such as the actual or preferred numbers of foreigners living in or entering Finland and the number of refugees that should be admitted into the country. Many news items about this topic were full of numbers, as the following example illustrates:

The number of foreign children living in Finland exceeds 10,000

There are over 10,000 foreign children living in Finland, half of them in the province of Uusimaa. The number of refugee children is 1,200 . Half of them have arrived in Finland alone, without their parents. (HS 4.9.1993)

Also with respect to this topic, the most frequently mentioned majority participant was parliament and the most frequent minority participant, yet again, the anonymous refugees. The huge imbalance in quotation also continued: $87 \%$ of quotations within the 
topic belonged to the majority and $13 \%$ to the minority. Besides using majority members as news sources far more often than minority participants, the intertextual features of the texts indicate that ready-made materials were utilized without much journalistic mediation. Namely, a discourse of Statistics - leaked from another societal domain, i.e. that of official, numerical information production - surfaced in the texts. This discourse represents ethnic minorities as an anonymous, non-identified mass, particularly in terms of the increase in their numbers.. Textually, this is achieved by frequent usage of numbers and comparisons. Frequent use of the verb 'be', which is typical in Finnish science texts (Karvonen 1995), contributes to the 'factual' character of this discourse. This is in comparison with action (material) verbs, which are usually favoured in news texts (Pietikäinen 2000). The majority members were often left unspecified and often featured by referring to a location in Finland, to Finland, in Helsinki, in the capital. The representation of ethnic minorities in terms of the increase in their numbers and the majority in terms of location reduces the multi-culturalization of Finland to a matter of numbers and changes, and dislocates it from the human aspect.

The topic of Immigration to Finland $(16 \%$ of 1,189$)$ came third in frequency. The texts about this topic were, too, populated by parliament and abstract 'refugees'. Also the voice was, again, given to the majority $(85 \%)$ and only occasionally to the minority $(15 \%)$. The texts focussed on the actual or potential immigration to Finland from three angles: migration, changes in the Soviet Union/Russia, and the global refugee situation. The migration aspect emphasized the need for Finland to accept migrants because of the considerable increase in the proportion of elderly people among its citizenry. This angle is exemplified in an excerpt from an editorial:

No alternatives left to the coming of migrants

The Finland that has closed its borders will change to a country of migration in 1990s. Foreigners are needed to get the work done and to keep the population figures steady. An employment expert predicts that the number of migrants to arrive in Finland will be as high as 300,000. (HS 16.12.1990)

The consequences of political and social changes in the former Soviet Union for Finland's situation constituted another angle. The following example from the beginning of a news report illustrates this.

Most Finns do not approve of the refugee flow from the East

According to a recent Gallup Poll, four out of five Finns consider that Finnish authorities should close the border to the large groups of refugees, possibly coming from the Soviet Union. About half of the people interviewed think that it is likely that hoards of refugees will try to cross the Eastern border. (HS 2.12.1990)

The third aspect of the topic of Immigration to Finland dealt with the global changes in both the number of migrants and the directions of migration, and its possible effects in Finland. Somalis arriving at the eastern border of Finland asking for asylum were seen as proof of this change. Consequently, the following types of headlines began to emerge:

Wave of immigration will flood the Nordic countries in the 1990's. (HS 11.3.1990)

The flow of refugees flooded reception centres

More Somalis coming again to Finland from the Soviet Union (HS 15.10.1990) 
These various aspects of Immigration to Finland feature a discourse that I call 'Nearing change'. It represents the newcomers as anonymous, numerous groups of people, which may also be compared with the destructive powers of nature, as in usage of metaphors such as wave of refugees, flood of people, flow of refugees or surge of migration. Their disturbing effect is also conveyed by the use of verbs: although the newcomers come and live, they also surge and flood. On the whole, the use of action (material) verbs emphasizes the construction of these events as happenings, changes and transitions. The Finns, instead, are represented as a homogeneous group of people - citizens, population, us, Finns - and via the state of Finland. Briefly, the discourse of Nearing change represents the newcomers as the bringers of a change to Finland, a change that will affect 'us'. Thus it could be speculated that, because the newcomers are at times described in words usually associated with natural catastrophes, there is also an implicit suggestion underlying this discourse that the change is for the worse.

\section{Controlling Ethnic Change - Legally and Politically}

The developments and discussions on political and legal aspects of multiculturalization of Finnish society were also frequently covered in HS. The topics of Finnish alien law $(15 \%$ of 1,189$)$ and Alien and refugee policy $(13 \%$ of 1,189$)$ came fourth and fifth in terms of frequency. During the period studied, Finnish legislation and refugee politics underwent drastic changes; the legislation was changed three times, shifting from being one of the strictest in Europe to a more tolerant one in 1988, just to be tightened up again in 1991. Further, under the pressure of international politics, the Finnish parliament tried to formulate a coherent guideline for Finland's official refugee policy, but during that time the three cabinets failed to accomplish this. The following headlines illustrate these topics:

\section{Danes frown upon Finnish refugee policy (HS 16.4.1985)}

Government decision: Finland admits 100 new refugees annually (HS 25.10.1985)

Legal changes, and often the resulting political discussions and debates, are a powerful tool to regulate and control the position of 'Others' in the country. In the coverage examined, the implications of legal actions were rarely explicated, but rather the texts focussed on 'technical' aspects of forming new laws and politics, thus contributing to the representation of these changes as abstract, without effects on the everyday lives of people, both the Finns and newcomers. This kind of detachment from people's lives was further emphasized by the patterns of participants mentioned in the texts and quotation; the most frequently mentioned majority participant was, with regard to both topics, the Finnish parliament and the most frequently mentioned minority participant, the unspecified refugees. In addition, majority participants were quoted five times more often than were minority members. The journalistic practice of following closely the events in the arena of politics and legislation and of granting relatively easy access to the official actors of these domains was, thus, realized in these texts, thereby contributing to the reporting of legal and political decisions from the majority perspective.

The 'technicalization' of these topics was reinforced by the intertextual characteristics of the texts. Namely, the texts about alien and refugee law and politics display a discourse of Political jargon. This shows in use of the passive voice, legal and political wording and long sentences. As a consequence, the texts remained on a rather general and abstract course of development, mainly dealing with the sayings and suggestions of various politicians, as the next excerpt from a news report illustrates: 


\section{Cabinet amends Aliens Act}

The cabinet aims at amending the new Aliens Act, which is now being processed by the Parliament. In its evening session on Wednesday, the cabinet agreed that the articles dealing with the right to appeal about the asylum decision will be rewritten in the bill that is now being kept waiting in the Legal Affairs Committee of the Parliament. (HS 18.10.1990)

The discourse of Political jargon contributes to a representation of ethnic and immigration issues as an administrative and legal question, and as such detached from the lives of people that these decisions impact. Because the people were rarely referred to, the discourse sets up the discussion between institutions rather than between groups of people or citizens.

\section{Crime and Racism: Unrest in Arcadia}

Also crime and racism were frequently covered in HS. The two topics were covered particularly during the early 1990s after the number of ethnic minority members had increased.

Crime $(12 \%$ of 1,189$)$ came sixth in frequency and the imbalance in quotations also characterizes these news texts: $88 \%$ of all quotations went to the majority and only $12 \%$ to members of the minority. These texts typically dealt with crimes committed by foreigners and members of ethnic minority groups in Finland. Among the crimes reported there were prostitution, shoplifting, organized crime, and drug crimes, as the following news headlines illustrate:

Customs seized $100 \mathrm{~g}$ of heroin from a Tanzanian man (HS 2.10.1992)

Eastern media are grouping for a foothold among Finnish power elite

Police keep an eye on Eastern crime (1.11.1993)

Crime is a frequent topic in news. Thus it can be expected that crime will receive its share of ethnic reporting, too. A problem arises, however, when crime news forms a significant part of the news publicity, brings up the ethnic background of the offender or connects certain types of crime to a specific ethnic group. All these problems surfaced in Helsingin Sanomat's news coverage. Crime news formed a significant part of the publicity of ethnic groups, the ethnic background of offenders was mentioned in the texts and headlines when such information had no obvious relevance. Moreover, one of the ethnic groups, namely the Russians, was predominantly covered in crime news only, thus labelling the whole group negatively. Indeed, in the crime news the most frequently mentioned minority participant was the Russians. The most frequently mentioned majority participant was the police. This kind of negative news publicity concerning the Russians seems to continue in the Finnish press; during a two-month period of media monitoring in 1999, crime news characterized the news publicity of the Russians, particularly in the regional newspapers located close to the eastern border (Raittila \& Kutilainen, 2000, pp. 56).

Issues of discrimination and racism (12\%) were also frequently covered and the experiences of minority members were typically focussed on. Also, issues concerning Finns' real or assumed attitudes towards ethnic minorities were taken up, as well as prejudices and xenophobia in Finland in general. The reasons for journalists "interest in racism and discrimination are varying. During the period under study, the phenom- 
enon appeared as new in Finland. From a minority point of view, these results indicate that although the crime aspect was prominent, the injustices of the situation were of interest as well. A pessimistic reading is that discrimination and racism, like crime news, attract attention because of their conflictual nature, as exemplified in the following news headlines:

Racial hatred sneaking its way into Finland (HS 9.9.1988)

Attitudes towards foreigners have got harder (HS 3.12.1993)

In terms of participants mentioned and quotation patterns the news texts about racism and discrimination differ from the other frequently covered topics. Namely, the most frequently mentioned majority participant was the Finns, i.e. citizens, local people, 'us'. The most typical minority participant was 'foreigners'. Although this category is also abstract and nonidentified, it shifted the attention from refugees and asylum seekers to foreigners, who can be in the country for various reasons, including marriage, work, etc. For the first time, the minority members were used more often as a news source and in quotations; $23 \%$ of quotations on this topic were from minority members and $77 \%$ from majority members. Although the imbalance is still clear, giving more voice to ethnic minorities indicates that this was seen as an issue on which the minority members' opinions and experiences have bearing.

Although these two topics, crime and discrimination, may come across as opposites, both feature trouble and disturbance. In my reading, many news items about these topics draw on the same discourse, which can be labelled as Troubles discourse. This discourse sets up a representation of ethnic minorities as being linked to disturbance, perhaps even as a source of the troubles that foreigners and the growing diversity of the population were believed to entail. True or alleged crimes by foreigners and racial conflicts were often brought up as an illustration of troubles and future problems. The Finns, in turn, are represented in this discourse in a dual way: first, as the people who are affected by these disturbances and, second, as the people who are called upon to act.

\section{Conclusions}

The Helsingin Sanomat news representations of ethnic minorities are characterized by polarization and anticipation of a change, most likely for the worse. Regardless of whether it was accomplished by the topics covered or comments made, the news typically emphasized the majority perspective, and contributed to the construction of ethnic minorities as Them as compared with the Finns as Us. The Finns were characteristically represented as actors, decision makers, masters of events - even though they at times suffered from the troubles brought on by the changing ethnic situation. Ethnic minorities were typically represented as faceless, nameless masses coming - uninvited - and causing trouble. In short, the ethnic majority was represented with the power to act and control, the ethnic minorities as lacking power, position and names.

News representations like these contribute to the fragmentation of society and set up borders between various ethnic groups. Rather than constructing a sense of community and belonging, HS news representations contribute to ethnic differentiation. Hence the HS news representations seem to be quite similar to those found in previous studies (see, e.g., Cottle, 2000; ter Wal, 2002). This kind of uniformity in ethnic representations in journalism, stretching over decades and different countries, may be something to worry about: the news media seem to favour similar representations in different social, political, and cultural situations and with different ethnic minorities. The frozenness of eth- 
nic representations in news implies that the otherness of ethnic minorities may be deeply embedded both in journalistic practices and in the societies in which they are functioning.

The reasons underlying the homogenous ethnic representations may be found in a combination of journalistic practices and the powerless positions of many ethnic minorities. Language problems and safety issues may explain, partly, why some ethnic minorities are not in the news or do not want news publicity. Another explanation might may be that few ethnic minority groups are able to offer PR services, and that may explain, to an extent, why news makers do not know about related issues or why journalists, given the time available, do not find individuals for comments. However, these are, in my opinion, minor obstacles; these are problems that journalists overcome on a daily basis when producing news items about different groups of people or different news sectors, such as the economy, foreign news, etc. Also the shortage of HS news coverage of the Sami, to whom the limitations mentioned above do not apply, gives an indication that the main explanations lie elsewhere (Pietikäinen 2003). One such explanation may be what could be called the invisibility of ethnic minorities: they are not considered part of the society or, alternatively, not an important part of the society in terms of the criteria of news making, i.e. important decision makers, consumers, opinion makers, etc. Consequently, news is not made about them. Although this kind of invisibility in news may also apply to many other groups of people, the very position of ethnic minorities means that they are not better represented anywhere else.

The findings of the present study offer some explanations for the ambivalence regarding the role of journalism in ethnic relations. The scarcity of the news about ethnic minorities, clear emphasis on the majority interests in the topics, and the imbalance in terms of quotations, access to news and reporting order, all give support to the claims made by ethnic minorities that news coverage about them is unfair and imbalanced. And because they are not quoted or do not get equal attention in topics of importance to them, news and news makers are discriminating against them. The ideals of objective news can be found underlying these arguments; according to these ideals, all parties involved should be treated equally. Journalists, instead, often argue that they apply the same rules when reporting about ethnic minorities as they apply in their news about anyone else, and that they treat ethnic minorities in an equal manner. Apparently, the news making practices entail that issues focussing on change, negativity, and people with status are covered, and that people belonging to the establishment and who are in power get access to news easily. The topics, people, and points of view important to many groups other than ethnic minorities are not covered either. It may well be that journalists do not, indeed, report on ethnic minorities differently from other groups that are seen as not belonging to the power elite, the decision makers or the celebrities. The minority position of ethnic groups, however, makes them vulnerable to frequent negative coverage: As one of the most powerful public spaces for ethnic representations, news portrayals contribute to the positions and rights of different ethnic groups.

\section{References}

Aikio, P. \& Aikio, A. (2001) Saavatko saamelaiset elää rauhassa. [Are the Sami allowed to live in peace] In Scheinin, M. \& Dahlgren, T. (eds.) Toteutuvatko saamelaisten ihmisoikeudet [Have the rights of the Sami been realized?] Helsinki: Helsinki University Press, pp. 92-119.

Allan, S. (1999) News Culture. Buckingham: Open University Press.

Barker, C. (1999) Television, Globalisation and Cultural Identities. Buckingham: Open University Press.

Bell, A. (1998) The Discourse Structure of News Stories. In Bell, A. \& Garrett, P. (eds.) Approaches to Media Discourse. Blackwell: Oxford, pp. 64-104. 
Brookes, H.J. (1995) A Suit, Tie and a Touch of Juju - The Ideological Construction of Africa: A Critical Discourse Analysis of News on Africa in the British press. Discourse \& Society 6(4), pp. 461-494.

Butterwegge, C. (1996) Mass Media, Immigrants and Racism in Germany. A Contribution to an Ongoing Debate. Communications 21(2), pp. 203-220.

Campbell, C. (1995) Race, Myth and the News. London: Sage.

Chouliaraki, L., \& Fairclough, N. (1999) Discourse in Late Modernity. Rethinking Critical Discourse Analysis. Edinburgh: Edinburgh University Press.

Critcher, C., Parker, M. \& Sondhi, R. (1977) Race in the Provincial Press: A Case Study of Five West Midlands Newspapers. In Halloran, D. (eds.). Ethnicity and the Media. An Analysis of Media Reporting in the United Kingdom, Canada and Ireland. Paris: Unesco, pp. 25-192.

Cottle, S. (2000) Introduction Media Research and Ethnic Minorities. Mapping the Field. In Cottle, S. (ed.). Ethnic Minorities and the Media. Buckingham: Open University Press, pp. 1-30.

Davydova, O. (2002) Interaktiivista identiteettipeliä - havaintoja paluumuutosta Suomeen [Interactive identity game - observations of the remigration to Finland] in Laihiala-Kankainen, S., Pietikäinen, S. \& Dufva, H. (eds.) Moniääninen Suomi. Kieli, kulttuuri ja identiteetti. Soveltavan Kielentutkimuksen keskus: Jyväskylän yliopisto, pp. 154-168.

Dufva, H. (2002) Dialogia suomalaisuudesta [A dialogue about Finnishness] in Laihiala-Kankainen, S., Pietikäinen, S. \& Dufva, H. (eds.) Moniääninen Suomi. Kieli, kulttuuri ja identiteetti. Soveltavan Kielentutkimuksen keskus: Jyväskylän yliopisto, pp. 21- 38.

Fairclough, N. (1992) Discourse and Social Change. Cambridge: Polity Press.

Fairclough, N. (1995) Media Discourse. London: Edward Arnold.

Fairclough, N. (2003) Analysing Discourse. Textual Analysis for Social Research. London: Routledge.

Fairclough, N. \& Wodak. R. (1997) Critical Discourse Analysis. An Overview, in van Dijk, T.A. (ed.) Discourse Analysis. A Multidisciplinary Introduction London: Sage, pp. 258-284.

Fairclough, N. (2001) Critical Discourse Analysis as a Method in Social Scientific Research. In Wodak, R. \& Meyer, M. (eds.) Methods of Critical Discourse Analysis London: Sage, pp. 121-138.

Fiske, J. (2000) White Watch. In Cottle, S. (ed.) Ethnic Minorities and the Media Buckingham: Open university press, pp 50-66.

Grossberg, L., Wartella, E. \& Whitney, D.C. (1998) Mediamaking, Mass Media in a Popular Culture. London: Sage.

Hall, S. (1996). Who Needs 'Identity'? In Hall, S. \& du Gay, P. (eds) Questions of Cultural Identity, London: Sage, pp. 1-17.

Hall, S. (1997) The Work of Representation. In Hall, S. (ed) Representation: Cultural Representations and Signifying Practices. London: Open University, pp. 13-75.

Halliday, M.A.K. (1994) An Introduction to Functional Grammar. Arnold: London (2 ${ }^{\text {nd }}$ Edition).

Hartley, J. (1996) Popular Reality. Journalism, Modernity, Popular Culture. London: Arnold.

Hartman, P. \& Husband, C. (1974) Racism and the Mass Media. London: Davis- Poynter.

Hujanen, J. \& Pietikäinen, S. (2004) Interactive Uses of Journalism. Encounters Between Technological Potential and Young People's News Practices. New Media \& Society 6(3), pp. 383-402.

Karvonen, P. (1995) Oppikirjateksti toimintana. [Course book text as action]. Helsinki: SKS.

Kennedy, R. (1998) Optimism, Pessimism and the Kerner Report. Media Studies Journal, Fall, pp. 76-82.

Lule, J. (1995) The Rape of Mike Tyson: Race, the Press and Symbolic Types. Critical Studies in Mass Communication 12, pp. 176-195.

Löwander, B. (1997) Rasism och antirasism på dagordningen. Umeå University, Department of Sociology (Doctoral theses Nr. 6 1997).

Newkirk, P. (1998) The Kerner Legacy. Media Studies Journal, pp. 58-65.

Parisi, P. (1998) The New York Times Looks at One Block in Harlem: Narratives of Race in Journalism. Critical Studies in Mass Communication 15, pp. 236-254.

Pietikäinen, S. \& Luostarinen, H (1997) Minorities in Finnish Publicity. Nordicom-Information 4, pp. 1932.

Pietikäinen, S. (2000) Discourses of Differentiation. Ethnic Representations in Newspaper Texts. Jyväskylä University (Studies in Communication 12).

Pietikäinen, S. (2003) Indigenous Identity in Print: Representations of the Sami in News Discourse. Discourse \& Society 14(5), pp. 581-612.

Pietikäinen, S. (forthcoming) Voicing Indigenous Community. The Case of the Sami Minority Media in Finland. In Lauk, E., Lauristin, M. \& Luostarinen, H. (eds.) (forthcoming) Media and Transformation of Identities. Hampton Press.

Pietilä, K. \& Sondermann, K. (1994) Sanomalehden yhteiskunta. [The society of the newspaper] Tampere: Vastapaino. 
Raittila, P (ed.) (2002) Etnisyys ja rasismi journalismissa [Ethnicity and racism in journalism]. Suomen journalistiliitto, mediakriittinen julkaisusarja 6. Tampere university press.

Raittila, P. \& Kutilainen, T. (2000) Rasismi ja etnisyys Suomen Sanomalehdissä syksyllä 1999. [Racism and ethnicity in the Finnish press in the autumn 1999] Tampereen yliopisto: Journlaismin tutkimusyksikkö.

Reisigl, M. \& Wodak, R (2001) Discourse and Discrimination. Rhetorics of Racism and Antisemitism. London: Routledge.

Ross, K (2000) In Whose Image? TV Criticism and Black Minority Viewers. In Cottle, S. (ed.). Ethnic Minorities and the Media. Buckingham: Open University Press, pp. 133-48.

Shah, H. \& Thornton, M.C. (1994) Racial Ideology in U.S Mainstream News Magazine Coverage of Blacklatino Interaction, 1980-1992. Critical Studies in Mass Communication 11, pp. 141-161.

Teo, P. (2000) Racism in the News: A Critical Discourse Analysis of News Reporting in Two Austrian Newspapers. Discourse \& Society 11(1), pp. 7-49.

Ter Wal, J. (2002) Racism and Cultural Diversity in the Mass Media. An Overview of Research and Examples of Good Practice in the EU Member States, 1995-2000. Vienna: European Monitoring Centre on Racism and Xenophobia:

Troyna, B. (1981) Public Awareness and the Media: A Study of Reporting on Race. London: Commission for Racial Equality.

Toolan, M. (1997) What is Critical Discourse Analysis and Why are People Saying Such Things about It? Language and literature 6(2), 83-103.

Tufte, T. (2003) Minority Youth, Media Uses and Identity Struggle. The Role of the Media in the Production of Locality. In Tufte, T. (ed.) Medierna, minoriterne og det multikulturelle samfund. Skandinaviske perspektiver. Göteborgs universitet: Nordicom, pp.181-198.

van Dijk, T.A. (1991) Racism and the Press. London: Routledge.

van Dijk, T.A. (2001) Multidisciplinary CDA: A Plea for Diversity, In Wodak, R. \& Meyer, M (eds.) Methods of Critical Discourse Analysis. London: Sage, pp. 95-120.

van Leeuwen, T. (1996) The Representation of Social Actors. In Caldas-Coulthard, C.R. \& Coulthard, M (eds.) Texts and Practices. Readings in Critical Discourse Analysis. London: Routledge, pp. 32-70.

Wodak, R. (1996) The Genesis of Racist Discourse in Austria since 1989. In Caldas-Coulthard, C.R. \& Coulthard, M. (eds.) Texts and Practices. Readings in Critical Discourse Analysis. London: Routledge, pp. 107-128.

Wodak, R., de Cilla, R., Reisigl, M. \& Liebhart, K (1999) The Discursive Construction of National Identity. Edinburgh: Edinburgh University Press.

Wodak, R. (2001) What CDA is About - A Summary of Its History, Important Concepts and Its Developments. In Wodak, R. \& Meyer, M (eds.) Methods of Critical Discourse Analysis. London: Sage, pp. 1-13.

Zelizer, B. (1997) Journalists as Interpretive Communities. In Berkowitz, D. (ed). Social Meaning of News. Thousand Oaks: Sage, pp. 401-19. 